\title{
PEMANFAATAN BERBAGAI JENIS LIMBAH RUMPUT LAUT TERHADAP PRODUKTIVITAS PADI SAWAH
}

\author{
Utilization of Different Types of Waste Seaweed on Productivity Rice \\ ${ }^{1 *}$ Hariyati, ${ }^{2}$ Bachrul Ibrahim, ${ }^{2}$ Asmita Ahmad \\ ${ }^{1}$ Alumni Jurusan Ilmu Tanah, Fakultas Pertanian, Universitas Hasanuddin, \\ ${ }^{2}$ Jurusan Ilmu Tanah, Fakultas Pertanian, Universitas Hasanuddin \\ *Corresponding email: bachrulibrahim@gmail.com
}

\begin{abstract}
Various ways have been made to increase the productivity of rice plants as a source of staple food of Indonesian society. One ofthem is the addition of nutrients in the soil (fertilization). Currently, the innovation use of seaweed as fertilizer is widely used in several countries in the world, because seaweed contains phosphorus, potassium, and some other micro elements. This study aimed to analyze the use of various types of waste seaweed to improve the productivity of paddy rice on the ground Vertisol. The study lasted from December 2014 through Sept. 2015, at Greenhouse, Teaching Farm, Faculty of Agriculture, University of Hasanuddin Makassar. The research method is a randomized block design consisting of eight treatments and six replications (48 pot experiment). Each treatment is $\mathrm{C} 0$ (control), $\mathrm{C} 1$ (fertilizer $\mathrm{N}$ $300 \mathrm{~kg} / \mathrm{ha}, \mathrm{P} 100 \mathrm{~kg} / \mathrm{ha}$ and $\mathrm{K} 100 \mathrm{~kg} /$ ha), G1 (Gracilaria $10 \mathrm{~g} / \mathrm{pot}$ ), G2 (Gracilaria $100 \mathrm{~g} /$ pot), S1 (Sargassum 10 g / pot), S2 (Sargassum 100 g / pot), K1 (Kappaphycus $10 \mathrm{~g} /$ pot), and K2 (Kappaphycus $100 \mathrm{~g} / \mathrm{pot}$ ). The addition of Sargassum seaweed fertilizer waste $100 \mathrm{~g} /$ pot and Kappaphycus dose of $100 \mathrm{~g} /$ pot can increase K-dd, Na- dd, base saturation, increase the value of $\mathrm{N}, \mathrm{P}, \mathrm{K}$, and Ca-dd, but administration with concentrations of $100 \mathrm{~g}$ / no maximum pot for rice crop production by causing toxicity in plants. The addition of seaweed fertilizer waste treatment Gracilaria $100 \mathrm{~g} /$ pot is effective in
\end{abstract}

improving Vertisol soil chemical properties and can provide maximum results for the productivity of rice plants.

Keywords: Rice, seaweed waste, vertisols.

\section{PENDAHULUAN}

Produksi padi pada tahun 2014 mengalami penurunan dibandingkan produksi padi pada tahun 2013. Di pulau Jawa penurunan produksi padi tahun 2014 sebesar 0,83 juta ton, sedangkan di luar pulau Jawa mengalami kenaikan sebanyak 0,39 juta ton. Penurunan produksi terjadi karena adanya penurunan luas panen yaitu 41,61 ribu ha $(0,30 \%)$ dan penurunan produktivitas sebesar $0,17 \mathrm{kuintal} / \mathrm{ha}(0,33$ \%) (BPS, 2015).

Lahan di Indonesia kapasitasnya cukup besar meskipun masih ada beberapa kendala dalam pemanfaatannya, salah satunya yaitu tanah Vertisol. Tanah Vertisol umumnya memiliki kendala pengelolaan lebih pada sifat fisiknya, karena adanya kandungan liat mudah mengembang dan mengkerut yang tinggi pada tanah Vertisol menjadi kendala utama dalam pengelolaan tanah ini, sehingga kelembabannya harus dijaga. salah satu cara untuk mnejaga kelembaban dan meningkatkan produktivitas pada tanah vertisol adalah dengan penambahan bahan organik.

Pemanfaatan rumput laut sebagai bahan pupuk sudah banyak digunakan di beberapa negara di dunia karena rumput 
laut mengandung fosfor, kalium, dan beberapa unsur mikro lainnya. Menurut Sharma (1992) pada areal persawahan yang telah diinokulasi dengan nitrogen dan rumput laut hijau biru dapat meningkatkan hasil produksi padi hingga $30 \%$.

Salah satu cara yang dapat dilakukan untuk memanfaatkan limbah rumput laut yaitu dengan cara mengolah limbah rumput laut menjadi pupuk organik. Limbah rumput laut juga dapat meningkatkan daya ikat air pada tanah Vertisol. Hal ini disebabkan karena limbah rumput laut memiliki kapasitas penyerapan dan penyimpanan air yang lebih tinggi (Aslan, 1995).

Penelitian ini bertujuan menganalisis pemanfaatan berbagai jenis limbah rumput laut untuk peningkatan produktivitas padi sawah pada tanah Vertisol. Kegunaan penelitian sebagai bahan informasi dan pertimbangan untuk pemerintah dan pihak-pihak terkait dalam pemanfaatan limbah rumput laut dan peningkatan produktivitas tanaman padi. Hipotesis penelitian ini yaitu bahwa penambahan limbah rumput laut dapat memperbaiki sifat kimia pada tanah Vertisol dan dapat meningkatkan produktivitas padi sawah.

\section{BAHAN DAN METODE}

Penelitian dilaksanakan di rumah kaca Teaching Farm, Fakultas Pertanian Universitas Hasanuddin Makassar. Sampel tanah asal tanah Vertisol diambil pada lapisan olah tanah sawah di Desa Banrimanirung Kecamatan Bangkala Barat Kabupaten Jeneponto.

Analisis tanah dan jaringan tanaman dilaksanakan di laboratorium Kimia dan Kesuburan Tanah jurusan Ilmu Tanah Fakultas Pertanian Universitas Hasanuddin, dan Laboratorium Balai Penelitian Tanah Pertanian (BPTP) Maros, Sulawesi-Selatan. Alat-alat yang digunakan dalam penelitian ini yaitu ayakan pasir, pot, label, timbangan, oven, alat untuk analisis tanah dan jaringan tanaman, alat-alat yang digunakan untuk analisis kimia tanah. Bahan-bahan yang digunakan, benih padi varietas Ciherang, pupuk ; Urea, SP-36, KCL, limbah rumput laut gracillaria, kappaphycus, dan sargassum, serta bahan-bahan yang digunakan untuk menganalisis tanah dan jaringan tanaman.

\section{Penelitian}

menggunakan

Rancangan Acak Kelompok yang terdiri atas 8 perlakuan dengan masing-masing perlakuan diulang sebanyak 6 kali, sehingga terdapat 48 pot percobaan. Masing-masing perlakuan yaitu : C0 (Kontrol atau tanpa pemberian pupuk); $\mathrm{C} 1$ (Pemberian pupuk N $\mathrm{P}$ dan $\mathrm{K}$ ); GA 1atau Gracilaria 1 dengan dosis $10 \mathrm{~g} /$ pot; GA 2 atau Gracilaria 2 dengan dosis 100 g/pot; S1 atau Sargassum 1 dengan dosis $10 \mathrm{~g} / \mathrm{pot}$; S2 atau Sargassum 2 dengan dosis $100 \mathrm{~g} / \mathrm{pot} ; \mathrm{K} 1$ atau Kappaphycus 1 dengan dosis 10 g/pot; dan K2 atau Kappaphycus 2 dengan dosis 100 $\mathrm{g} /$ pot.

Panen dilakukan pada saat tanaman padi sudah matang fisiologis yaitu dengan melihat warna bulir yang menguning, keras (susah dipecah dengan kuku), dan anakan yang menguning. Kisaran waktu panen dilakukan pada saat padi berumur 88 HST sampai berumur 97 HST. Panen dilakukan secara tidak serentak dikarenakan adanya perbedaan waktu pada saat keluarnya malai. Tanaman padi pada perlakuan G1 (penambahan pupuk limbah rumput laut Gracilaria dosis $100 \mathrm{~g} /$ pot) dipanen pada umur 88 HST. Perlakuan CO (kontrol), perlakuan $\mathrm{S} 1$, dan perlakuan $\mathrm{K} 1$ dipanen pada umur 89 HST. Perlakuan G2 dipanen pada umur 93 HST. Perlakuan C1 dipanen pada umur 94 HST. Perlakuan S2, K2 dipanen pada umur 97 HST.

Parameter Pengamatan terdiri dari tinggi tanaman, jumlah daun tanaman, jumlah anakan, jumlah malai, berat kering bagian atas tanaman, analisis bulir padi, meliputi ; bentuk dan kandungan hara $\mathrm{N}, \mathrm{P}$, 
dan K. Analisis tanah meliputi analisis sebelum dan setelah perlakuan. Metode analisis sifat kimia tanah Vertisol, rumput laut dan bulir padi ditunjukkan pada tabel 1 . Analisis data menggunakan SPSS 16 dengan uji Duncan pada taraf $\alpha=0,05$.

Tabel 1. Metode analisis sifat kimia tanah, bulir padi, dan limbah rumput laut.

\begin{tabular}{|c|c|}
\hline Parameter & Metode \\
\hline \multicolumn{2}{|l|}{ A. Analisis Tanah } \\
\hline C-organik (\%) & Walkley and Black \\
\hline Ntotal (\%) & Kjeldahl \\
\hline \multicolumn{2}{|l|}{$\mathrm{C} / \mathrm{N}$} \\
\hline P205 potensial (mg/100 gr) & HCL $25 \%$ \\
\hline K20 potensial (mg/100 gr) & HCL $25 \%$ \\
\hline pH H2O & Elektrometri \\
\hline KTK (cmol/ kg tanah) & Amonium Asetat (NH40AC) \\
\hline \multicolumn{2}{|l|}{ Susunan Kation: } \\
\hline \multicolumn{2}{|l|}{$\mathrm{K}(\mathrm{cmol} / \mathrm{kg})$} \\
\hline \multicolumn{2}{|l|}{$\mathrm{Na}(\mathrm{cmol} / \mathrm{kg})$} \\
\hline $\mathrm{Mg}(\mathrm{cmol} / \mathrm{kg})$ & 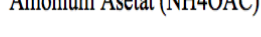 \\
\hline \multicolumn{2}{|l|}{$\mathrm{Ca}(\mathrm{cmol} / \mathrm{kg})$} \\
\hline \multicolumn{2}{|l|}{ Kejenuhan Basa (\%) } \\
\hline \multicolumn{2}{|l|}{ B. Analisis Bulir Padi } \\
\hline $\mathrm{N}$ & Kjeldahl \\
\hline $\mathrm{P}$ & $\mathrm{HClO4}$ \\
\hline $\mathrm{K}$ & Ekstraksi NH40 ac $1 \mathrm{~N} \mathrm{pH} 7$ \\
\hline Kadar air & Gravimetri \\
\hline \multicolumn{2}{|l|}{ C. Analisis Rumput Laut } \\
\hline $\mathrm{N}$ & Kjeldahl \\
\hline $\mathrm{P}$ & $\mathrm{HClO4}$ \\
\hline $\mathrm{K}$ & Ekstraksi NH40 ac $1 \mathrm{~N} \mathrm{pH} 7$ \\
\hline Kadar air & Gravimetri \\
\hline
\end{tabular}

\section{HASIL DAN PEMBAHASAN}

\section{Analisis sifat kimia tanah Vertisol}

Hasil analisis tanah vertisol (Tabel 2) menunjukkan bahwa kandungan bahan organik di dalam tanah meningkat setelah perlakuan limbah rumput laut Gracilaria dosis $100 \mathrm{~g} /$ pot yaitu 2,48 \% (sedang) meningkat jika dibandingkan dengan perlakuan $\mathrm{C} 1$ (penambahan pupuk $\mathrm{N}, \mathrm{P}$, dan $\mathrm{K}$ ) yaitu 2,07 \% (sedang). Nilai kandungan bahan organik tanah sebelum perlakuan yaitu 13,55 (sedang). Penambahan pupuk dari limbah rumput laut sebagai pupuk organik menambah unsur hara di dalam tanah, meningkatkan kapasitas tukar kation
(KTK), dan juga berperan dalam peningkatan ketersediaan unsur hara fosfat di dalam tanah (Damanik et al, 2010), selain itu menurut Foth (1994) dengan enambahkan pupuk organik ke dalam tanah tidak hanya dapat memperbaiki sifat kimia tanah tetapi juga dapat memperbaiki sifat fisik tanah sehingga proses aerasi menjadi lebih baik untuk perkembangan akar tanaman.

Nisbah $\mathrm{C} / \mathrm{N}$ merupakan indikator yang dapat menunjukkan tingkat dari proses dekomposisi yang terjadi di dalam tanah dari penambahan bahan organik. Nilai $\mathrm{C} / \mathrm{N}$ pada hasil analisis awal yaitu 13,55 \% (sedang), sedangkan hasil analisis akhir setelah perlakuan nilai $\mathrm{C} / \mathrm{N}$ tertinggi diperoleh dari perlakuan $\mathrm{C} 0$ (kontrol) yaitu $28,00 \%$ (sangat tinggi) sehingga proses immobilisasi cenderung meningkat, nilai $\mathrm{C} / \mathrm{N}$ terbaik dihasilkan dari perlakuan $\mathrm{G} 2$ (penambahan pupuk limbah rumput laut Gracilaria dosis $100 \mathrm{~g} /$ pot) yaitu 14,59\% (sedang) karena meningkatnya mineralisasi. Hal ini sesuai dengan pendapat (Hanafiah, 2005) bahwa nisbah $\mathrm{C} / \mathrm{N}$ yang memiliki nilai lebih kecil dari 20 menunjukkan terjadinya mineralisasi $\mathrm{N}$, jika lebih besar dari 30 berarti terjadi immobilisasi N, sedangkan jika diantara 2030 berarti mineralisasi cenderung seimbang dengan immobilisasi.

Pada hasil analisis awal kandungan $\mathrm{K}$ di dalam tanah yaitu 27,63 mg $100 \mathrm{~g}^{-1}$ (sedang), sedangkan pada hasil analisis akhir atau setelah perlakuan kandungan unsur hara $\mathrm{K}$ meningkat. Nilai $\mathrm{K}$ tertinggi diperoleh dari perlakuan G2 (penambahan pupuk limbah rumput laut Gracilaria dosis $100 \mathrm{~g} /$ pot) yaitu 50,63 mg $100 \mathrm{~g}^{-1}$ (tinggi), karena hasil analisis limbah rumput laut Gracilaria mengandung K sebanyak 23,48 $\%$. Menurut Indranada (1989) sumber kalium berasal dari pupuk organik dan mineral-mineral kalium.

Reaksi tanah (pH) menentukan mudah tidaknya unsur hara dapat diserap oleh tanaman, unsur hara yang mudah 
diserap oleh akar tanaman yaitu pada $\mathrm{pH}$ sekitar netral karena pada $\mathrm{pH}$ tersebut unsur hara mudah larut di dalam air. Nilai $\mathrm{pH}$ pada perlakuan G2 (penambahan pupuk limbah rumput laut Gracilaria dosis 100 g/pot) yaitu 7,41 (netral) sedangkan pada perlakuan $\mathrm{C} 1$ (penambahan pupuk $\mathrm{N}, \mathrm{P}$, dan K) nilai $\mathrm{pH}$ tanah yaitu 7,38 (netral). Menurut Hardjowigeno (2010) pH tanah menentukan unsur hara mudah diserap atau tidak boleh akar tanaman. $\mathrm{pH}$ tanah yang netral akan memudahkan akar tanaman untuk meyerap unsur hara karena pada $\mathrm{pH}$ netral unsur hara mudah larut dalam air, tetapi pada tanah alkalis unsur hara $\mathrm{P}$ tidak dapat diserap oleh tanaman karena unsur hara P difiksasi oleh Ca.

Kapasitas tukar kation (KTK) merupakan sifat kimia yang sangat erat kaitannya dengan kesuburan tanah. Hasil analisis awal diperoleh nilai KTK yaitu 20,04 me $100 \mathrm{~g} \mathrm{tanah}^{-1}$ (sedang), sedangkan hasil analisis akhir diperoleh nilai KTK tertinggi yaitu 33,10 me $100 \mathrm{~g} \mathrm{tanah}{ }^{-1}$ (tinggi) dari perlakuan G2 (penambahan pupuk limbah rumput laut Gracilaria dosis $100 \mathrm{~g} / \mathrm{pot}$ ) dan nilai KTK terendah yaitu $22,53 \mathrm{me} 100 \mathrm{~g} \operatorname{tanah}^{-1}$ (tinggi) dari perlakuan S2 (penambahan pupuk limbah rumput laut Sargassum dosis $100 \mathrm{~g} / \mathrm{pot}$ ). Nilai KTK pada tanah Vertisol meningkat setelah diberikan pupuk organik dari limbah rumput laut. Menurut Wibisono dan Basri (1993) senyawa anorganik yang terkandung di dalam bahan organik akan mengalami proses dekomposisi dan menghasilkan nutrisi untuk tanaman berupa nitrogen dan phosphor, serta dapat meningkatkan kapasitas tukar kation (KTK) di dalam tanah.

Tanah-tanah yang memiliki kandungan bahan organik tinggi atau dengan kadar liat tinggi memiliki nilai KTK yang lebuh tinggi jika dibandingkan dengan tanah-tanah yang memiliki kandungan bahan organik yang rendah atau tanah berpasir. Menurut Hardjowigeno (2010) tanah yang memiliki nilai KTK yang tinggi mampu menyediakan unsur hara yang baik untuk pertumbuhan tanaman jika dibandingkan dengan tanah yang memiliki nilai KTK rendah. Tanah dengan KTK tinggi jika didominasi oleh kation basa, $\mathrm{Ca}$, $\mathrm{Mg}, \mathrm{K}$, dan $\mathrm{Na}$ (kejenuhan basa tinggi) akan meningkatkan kesuburan tanah karena unsur-unsur hara tersebut tidak mudah mengalami pencucian oleh air.

\section{Produktivitas tanaman padi}

Pada pengamatan tinggi tanaman (Tabel 3), jumlah daun (Tabel 4), jumlah anakan (Tabel 5), jumlah malai (Tabel 6) dan jumlah berat kering atas tanaman padi (Tabel 7), produktivitas maksimum diperoleh dari perlakuan $\mathrm{C} 1$ (penambahan pupuk N, P, dan K) sebesar 45,33 gr dan perlakuan G2 (penambahan pupuk limbah rumput laut Gracilaria dosis $100 \mathrm{~g} / \mathrm{pot}$ ) berat kering atas tanaman yaitu 25,63 gr. Produktivitas minimum diperoleh dari perlakuan K2 (penambahan pupuk limbah rumput laut Kappaphycus dosis 100 g/pot) yaitu sebesar 5,42 gr.

Pada perlakuan G2 (penambahan pupuk limbah rumput laut Gracilaria dosis $100 \mathrm{~g} / \mathrm{pot}$ ) pemupukan hanya dilakukan satu kali yaitu sebelum penanaman dengan cara menghomogenkan pupuk dari limbah rumput laut Gracilaria dosis $100 \mathrm{~g} / \mathrm{pot}$ dengan tanah selama dua minggu sebelum penanaman, meskipun pemupukan hanya dilakukan sebanyak satu kali tetapi nilai rata-rata dari pengamatan setiap minggu menunjukkan produktivitas tanaman pada perlakuan G2 tidak berbeda jauh dengan perlakuan C1. Perlakuan G2 lebih efisien terhadap pemupukan dibandingkan perlakuan $\mathrm{C} 1$. 
Tabel 2. Hasil analisis tanah sebelum perlakuan dan setelah perlakuan dengan penambahan limbah rumput laut.

\begin{tabular}{|c|c|c|c|c|c|c|c|c|c|c|c|c|}
\hline \multirow{3}{*}{ Sampel } & \multicolumn{12}{|c|}{ Analisis Sifat Kimia Tanah Asal Tanah Vertisol Jeneponto } \\
\hline & \multirow[b]{2}{*}{$\mathrm{C}(\%)$} & \multirow[b]{2}{*}{$\mathbf{N}(\%)$} & \multirow[b]{2}{*}{$\mathrm{C} / \mathrm{N}$} & \multirow[b]{2}{*}{$\begin{array}{l}\text { P205 (mg/ } \\
100 \mathrm{gr})\end{array}$} & \multirow[b]{2}{*}{$\begin{array}{c}\text { K20 (mg/ } \\
100 \text { gr) }\end{array}$} & \multirow[b]{2}{*}{$\begin{array}{c}\mathrm{pH} \\
\mathrm{H} 2 \mathrm{O}\end{array}$} & \multirow[b]{2}{*}{$\underset{(\mathrm{cmol} / \mathrm{kg})}{\mathrm{KTK}}$} & \multicolumn{4}{|c|}{ Susunan Kation } & \multirow[b]{2}{*}{$\begin{array}{c}\text { Kejenuhan } \\
\text { Basa (\%) }\end{array}$} \\
\hline & & & & & & & & $\begin{array}{c}\mathrm{K} \\
(\mathrm{cmol} / \mathrm{kg})\end{array}$ & $\begin{array}{c}\mathrm{Na} \\
(\mathrm{cmol} / \mathrm{kg})\end{array}$ & $\begin{array}{c}\mathrm{Mg} \\
(\mathrm{cmol} / \mathrm{kg}\end{array}$ & $\begin{array}{c}\mathrm{Ca} \\
(\mathrm{cmol} / \mathrm{kg})\end{array}$ & \\
\hline $\begin{array}{l}\text { sebelum } \\
\text { perlakuan }\end{array}$ & $\begin{array}{c}2,71 \\
\text { sedang }\end{array}$ & $\begin{array}{c}0,20 \\
\text { rendah }\end{array}$ & $\begin{array}{c}13,55 \\
\text { sedang }\end{array}$ & $\begin{array}{c}1,18 \\
\text { sgt rendah }\end{array}$ & $\begin{array}{c}27,63 \\
\text { sedang }\end{array}$ & $\begin{array}{c}7,46 \\
\text { netral }\end{array}$ & $\begin{array}{c}20,04 \\
\text { sedang }\end{array}$ & $\begin{array}{c}0,99 \\
\text { tinggi }\end{array}$ & $\begin{array}{c}0,40 \\
\text { sedang }\end{array}$ & $\begin{array}{c}5,05 \\
\text { tinggi }\end{array}$ & $\begin{array}{c}7,31 \\
\text { sedang }\end{array}$ & $\begin{array}{l}68,61 \\
\text { tinggi }\end{array}$ \\
\hline $\mathrm{VCO}$ & $\begin{array}{c}2,80 \\
\text { sedang }\end{array}$ & $\begin{array}{c}0,10 \\
\text { rendah }\end{array}$ & $\begin{array}{c}28,00 \\
\text { sgt tinggi }\end{array}$ & $\begin{array}{l}44,83 \\
\text { Tinggi }\end{array}$ & $\begin{array}{r}19,36 \\
\text { rendah }\end{array}$ & $\begin{array}{c}7,52 \\
\text { netral }\end{array}$ & $\begin{array}{l}31,31 \\
\text { tinggi }\end{array}$ & $\begin{array}{c}0,22 \\
\text { rendah }\end{array}$ & $\begin{array}{c}0,66 \\
\text { sedang }\end{array}$ & $\begin{array}{l}5,76 \\
\text { tinggi }\end{array}$ & $\begin{array}{c}9,27 \\
\text { sedang }\end{array}$ & $\begin{array}{c}51 \\
\text { sedang }\end{array}$ \\
\hline $\mathrm{VCl}$ & $\begin{array}{c}2,07 \\
\text { sedang }\end{array}$ & $\begin{array}{c}0,11 \\
\text { rendah }\end{array}$ & $\begin{array}{l}18,81 \\
\text { tinggi }\end{array}$ & $\begin{array}{c}37,40 \\
\text { Sedang }\end{array}$ & $\begin{array}{c}25,30 \\
\text { sedang }\end{array}$ & $\begin{array}{c}7,38 \\
\text { netral } \\
\end{array}$ & $\begin{array}{l}28,51 \\
\text { tinggi }\end{array}$ & $\begin{array}{c}0,32 \\
\text { rendah }\end{array}$ & $\begin{array}{c}0,58 \\
\text { sedang }\end{array}$ & $\begin{array}{c}4,34 \\
\text { tinggi }\end{array}$ & $\begin{array}{c}9,62 \\
\text { sedang }\end{array}$ & $\begin{array}{c}52 \\
\text { sedang }\end{array}$ \\
\hline VS1 & $\begin{array}{c}2,61 \\
\text { sedang }\end{array}$ & $\begin{array}{c}0,14 \\
\text { rendah }\end{array}$ & $\begin{array}{l}18,64 \\
\text { tinggi }\end{array}$ & $\begin{array}{c}33,91 \\
\text { Sedang }\end{array}$ & $\begin{array}{c}24,65 \\
\text { sedang }\end{array}$ & $\begin{array}{c}7,46 \\
\text { netral }\end{array}$ & $\begin{array}{l}32,30 \\
\text { tinggi }\end{array}$ & $\begin{array}{c}0,14 \\
\text { rendah }\end{array}$ & $\begin{array}{c}0,75 \\
\text { sedang }\end{array}$ & $\begin{array}{c}5,93 \\
\text { tinggi }\end{array}$ & $\begin{array}{c}8,51 \\
\text { sedang }\end{array}$ & $\begin{array}{c}47 \\
\text { sedang }\end{array}$ \\
\hline VS2 & $\begin{array}{c}2,57 \\
\text { sedang }\end{array}$ & $\begin{array}{c}0,17 \\
\text { sedang }\end{array}$ & $\begin{array}{c}15,11 \\
\text { sedang }\end{array}$ & $\begin{array}{c}36,82 \\
\text { sedang }\end{array}$ & $\begin{array}{c}32,21 \\
\text { sedang }\end{array}$ & $\begin{array}{c}7,53 \\
\text { netral } \\
\end{array}$ & $\begin{array}{r}22,53 \\
\text { tinggi } \\
\end{array}$ & $\begin{array}{c}2,21 \\
\text { sgt tinggi }\end{array}$ & $\begin{array}{c}3,22 \\
\text { sgt tinggi }\end{array}$ & $\begin{array}{c}4,81 \\
\text { tinggi } \\
\end{array}$ & $\begin{array}{c}10,81 \\
\text { sedang }\end{array}$ & $\begin{array}{c}93 \\
\text { sgt tinggi }\end{array}$ \\
\hline VK1 & $\begin{array}{c}2,27 \\
\text { sedang }\end{array}$ & $\begin{array}{c}0,21 \\
\text { sedang }\end{array}$ & $\begin{array}{l}10,81 \\
\text { rendah }\end{array}$ & $\begin{array}{c}35,37 \\
\text { sedang }\end{array}$ & $\begin{array}{c}24,15 \\
\text { sedang }\end{array}$ & $\begin{array}{c}7,48 \\
\text { netral } \\
\end{array}$ & $\begin{array}{l}32,50 \\
\text { tinggi }\end{array}$ & $\begin{array}{c}0,56 \\
\text { sedang }\end{array}$ & $\begin{array}{c}0,65 \\
\text { sedang }\end{array}$ & $\begin{array}{c}5,46 \\
\text { tinggi } \\
\end{array}$ & $\begin{array}{c}8,49 \\
\text { sedang }\end{array}$ & $\begin{array}{c}47 \\
\text { sedang }\end{array}$ \\
\hline VK2 & $\begin{array}{c}2,45 \\
\text { sedang }\end{array}$ & $\begin{array}{c}0,15 \\
\text { rendah }\end{array}$ & $\begin{array}{l}16,33 \\
\text { tinggi }\end{array}$ & $\begin{array}{c}68,71 \\
\text { sgt tinggi }\end{array}$ & $\begin{array}{l}52,32 \\
\text { tinggi }\end{array}$ & $\begin{array}{c}7,46 \\
\text { netral } \\
\end{array}$ & $\begin{array}{l}28,51 \\
\text { tinggi }\end{array}$ & $\begin{array}{c}1,52 \\
\text { sgt tinggi }\end{array}$ & $\begin{array}{c}2,33 \\
\text { sgt tinggi }\end{array}$ & $\begin{array}{c}3,68 \\
\text { tinggi } \\
\end{array}$ & $\begin{array}{l}11,46 \\
\text { tinggi }\end{array}$ & $\begin{array}{c}67 \\
\text { tinggi }\end{array}$ \\
\hline VG1 & $\begin{array}{c}2,86 \\
\text { sedang }\end{array}$ & $\begin{array}{c}0,18 \\
\text { rendah }\end{array}$ & $\begin{array}{c}15,89 \\
\text { sedang }\end{array}$ & $\begin{array}{c}30,27 \\
\text { sedang }\end{array}$ & $\begin{array}{c}21,65 \\
\text { sedang }\end{array}$ & $\begin{array}{c}7,46 \\
\text { netral } \\
\end{array}$ & $\begin{array}{l}31,31 \\
\text { tinggi }\end{array}$ & $\begin{array}{c}0,22 \\
\text { rendah } \\
\end{array}$ & $\begin{array}{c}0,42 \\
\text { sedang }\end{array}$ & $\begin{array}{c}4,75 \\
\text { tinggi } \\
\end{array}$ & $\begin{array}{c}8,49 \\
\text { sedang }\end{array}$ & $\begin{array}{c}44 \\
\text { sedang }\end{array}$ \\
\hline VG2 & $\begin{array}{c}2,48 \\
\text { sedang }\end{array}$ & $\begin{array}{c}0,17 \\
\text { rendah }\end{array}$ & $\begin{array}{c}14,59 \\
\text { sedang }\end{array}$ & $\begin{array}{c}40,61 \\
\text { sedang }\end{array}$ & $\begin{array}{l}50,63 \\
\text { tinggi }\end{array}$ & $\begin{array}{c}7,41 \\
\text { netral } \\
\end{array}$ & $\begin{array}{l}33,10 \\
\text { tinggi }\end{array}$ & $\begin{array}{c}1,98 \\
\text { sgt tinggi }\end{array}$ & $\begin{array}{c}1,56 \\
\text { sgt tinggi }\end{array}$ & $\begin{array}{c}5,23 \\
\text { tinggi }\end{array}$ & $\begin{array}{l}11,11 \\
\text { tinggi }\end{array}$ & $\begin{array}{c}60 \\
\text { sedang }\end{array}$ \\
\hline
\end{tabular}

Kriteria Balai Penelitian Tanah, 2005.

Tabel 3. Tinggi tanaman padi

\begin{tabular}{|c|c|c|c|c|c|c|c|c|c|c|c|c|}
\hline \multirow{2}{*}{$\begin{array}{c}\text { PERLAKTTIX } \\
\text { CO (Kontrol tanpa petlakuan) }\end{array}$} & \multicolumn{12}{|c|}{ Nilai rata-rata setiap minggu $(\mathrm{cm})$} \\
\hline & $22,93^{\mathrm{ki}}$ & 35,5770 & $48,82^{\circ}$ & 62,784 & 68,47 & $72,00^{\circ}$ & $72,1^{5 n}$ & 72,08 & $73,23^{5 n}$ & $77,67^{\mathrm{n}}$ & 83,29 & 84,59 \\
\hline $\mathrm{Cl}(\mathrm{N}, \mathrm{P}, \mathrm{danK})$ & 26,384 & 34,92 & 49,059 & $63,6 ?$ & $69,83^{\circ}$ & $77,50^{\circ}$ & 80,824 & 81,784 & 80,75 & $\$ 5,42^{4}$ & 94,67 & $94,45^{\circ}$ \\
\hline S1 (sargassum $10 \mathrm{~g}$ pot) & $25,92^{*}$ & $35,48 \mathrm{n}$ & $49,30^{\circ}$ & $63,45^{4}$ & 67,524 & $70,33^{\mathrm{A}}$ & $71,87 \mathrm{t}$ & 71,57 & 72,42 & $75,000^{\circ}$ & $83,63^{3}$ & $84,08^{\circ}$ \\
\hline \$2 (sargassum $100 \mathrm{~g}$ pot) & $20,15^{\circ}$ & $25,30^{\mathrm{s}}$ & $31,68^{\circ}$ & $40,48:$ & $42,03^{\circ}$ & 50,92 & $56,27 \%$ & 35,78 & $\$ 8,00^{\circ}$ & 62,28 & $65,12^{\circ}$ & $68,50^{\circ}$ \\
\hline KI (tappaphyews 10 g pot) & $23,38 \mathrm{w}$ & $35,63^{\mathrm{n}}$ & $50,77^{\mathrm{Ha}}$ & $63,60^{\circ}$ & 67,48 & 70,824 & 70,25 & 68997 & 71,39 & $76,42^{2}$ & 81,122 & 81,38 \\
\hline $\mathrm{K} 2$ (tappaphicu: 100 g pot) & 17,20 & $20,32^{4}$ & 24,92 & 30,234 & $33,43^{4}$ & 34874 & 36,384 & 40,284 & $48,33^{\circ}$ & $47,92^{4}$ & $48,50^{\circ}$ & 53,384 \\
\hline GI (gracliaria $10 \mathrm{~g}$ pot) & $25,75 \mathrm{Bt}$ & 39,02 & $35,42^{2}$ & $69,3^{\circ}$ & 70,594 & $7283^{\circ}$ & $73,77^{n}$ & $74,47 \mathrm{~A}$ & $74,50^{\circ \mathrm{h}}$ & $83,33^{\mathrm{n}}$ & 84,72 & 84287 \\
\hline Q2. (eracilaria 100 g pot) & $22.10^{\mathrm{t}}$ & 32,37 & 42,07 & $5283^{\circ}$ & 51,599 & $6450^{\circ}$ & $70,33^{3}$ & $73,82^{\circ}$ & $74,33^{\mathrm{m}}$ & $72,00^{\circ}$ & 83,77 & 83.833 \\
\hline
\end{tabular}

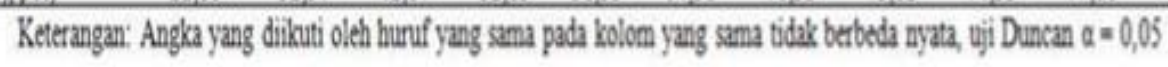


Tabel 4. Jumlah Daun Tanaman Padi

\begin{tabular}{|c|c|c|c|c|c|c|c|c|c|c|}
\hline \multirow{2}{*}{$\frac{\text { PERLAKUAN }}{C O \text { (Kontrol tanpa periakuan) }}$} & \multicolumn{10}{|c|}{ Nilai rata-rata setiap minggu } \\
\hline & $11,33^{\text {ab }}$ & $22,83^{\text {ab }}$ & $36,50^{b}$ & $39,83^{\circ}$ & 39,33 & 43,336 & 40,005 & $37,33^{\mathrm{c}}$ & $26,83 \mathrm{c}$ & $19,33 \mathrm{c}$ \\
\hline $\mathrm{Cl}(\mathrm{N}, \mathrm{P}, \mathrm{dan} \mathrm{K})$ & $12,00^{3}$ & $26,67 \mathrm{a}$ & 53,838 & $74,00^{3}$ & $79,50^{\mathrm{3}}$ & $76,83^{8}$ & $78,00^{3}$ & $82,83^{\circ}$ & $73,67^{8}$ & $53,67 \mathrm{a}$ \\
\hline S1 (sargassum $10 \mathrm{~g}$ pot) & 12,338 & $22,83^{\text {ab }}$ & $31,50^{\circ}$ & $32,00^{\circ}$ & 31,836 & $34,677^{\circ}$ & 32,83 cd & $29,00 \mathrm{~cd}$ & $22,33 \mathrm{~cd}$ & $14,67 \%$ \\
\hline$\$ 2$ (sargassum $100 \mathrm{~g}$ pot) & $3,50^{\circ}$ & 5,336 & $7,50 \mathrm{~s}$ & $10,00 \mathrm{c}$ & $11,83^{\mathrm{d}}$ & $14,00^{d}$ & $16,00^{9}$ & $17,33^{\mathrm{ef}}$ & $16,50^{\text {da }}$ & $14,67 c^{\circ}$ \\
\hline K1 (kappaphycus $10 \mathrm{~g}$ pot) & $12,33 \mathrm{~B}$ & $26,00^{\circ}$ & $32,50^{\circ}$ & $32,50^{\circ}$ & $31,677^{\circ}$ & $36,00 \%$ & 35,33 od & 31,50 od & $24,67^{\mathrm{cd}}$ & $17,33 \mathrm{c}$ \\
\hline $\mathrm{K} 2$ (kappaphycus $100 \mathrm{gpot}$ ) & $2,17{ }^{\circ}$ & 2,835 & $3,83 \mathrm{c}$ & $4,33 \mathrm{c}$ & $6,00^{4}$ & $6,50^{4}$ & $7,67 \%$ & $8,83^{f}$ & $10,67^{\mathrm{e}}$ & $10,50 \mathrm{c}$ \\
\hline G1 (gracilaria $10 \mathrm{~g}$ pot) & $14,67^{8}$ & $25,50^{\circ}$ & $30,00^{\circ}$ & $29,83^{\circ}$ & $31,50^{\circ}$ & $32,677^{\circ}$ & $29,50^{d}$ & $26,50^{\text {dh }}$ & 19,50 ode & $15,00 \mathrm{~s}$ \\
\hline G2 (gracilaria 100 gpot) & $8,50^{b}$ & $15,67^{\mathrm{b}}$ & $26,50^{\circ}$ & $39,33^{\circ}$ & $52,67^{\mathrm{b}}$ & $60,17^{\circ}$ & $62,33^{\mathrm{b}}$ & $61,33^{b}$ & $49,00^{b}$ & $38,33^{\circ}$ \\
\hline
\end{tabular}

Tabel 5. Jumlah anakan tanaman padi

\begin{tabular}{|c|c|c|c|c|c|c|c|c|c|c|}
\hline \multirow{2}{*}{$\frac{\text { PERLAKTAN }}{\text { CO (Kontrol tanpa perlakuan) }}$} & \multicolumn{10}{|c|}{ Nilai rata-rata setiap minggu } \\
\hline & $2,50^{2}$ & $7,50^{\circ}$ & $10,50^{\circ}$ & $11,50^{5}$ & $11,67^{\mathrm{x}}$ & $11,83^{\mathrm{x}}$ & $12,17^{\circ}$ & $11,00^{\circ}$ & $9,50^{\circ}$ & $8,33^{\circ}$ \\
\hline $\mathrm{Cl}(\mathrm{N}, \mathrm{P}, \operatorname{dan} \mathrm{K})$ & $2,50^{2}$ & $8,50^{4}$ & $13,67^{7}$ & $23,17^{7}$ & $23,67^{\circ}$ & 22,674 & $23,83^{4}$ & $23,17^{4}$ & $21,00^{4}$ & $17,83^{3}$ \\
\hline $\mathrm{S1}$ (sargassum $10 \mathrm{~g}$ pot) & $2,833^{2}$ & $6,50^{\text {th }}$ & $8,83^{\circ}$ & $9,67^{\circ}$ & $10,00^{\circ}$ & $10,17 \mathrm{c}$ & 10,00 क & $9,67^{\circ}$ & 7,3306 & 5,8300 \\
\hline$\$ 2$ (sargassum $100 \mathrm{~g}$ pot) & 1,33 & $1,67 \%$ & $2,50^{\circ}$ & $3,83^{6}$ & $4,00^{4}$ & $4,67^{\mathrm{hn}}$ & 5,004 & $5,17^{6 \mathrm{r}}$ & 5,679 & $5,67^{64}$ \\
\hline $\mathrm{K} 1$ (rappaphycus $10 \mathrm{gpot}$ ) & $3,00^{2}$ & $8,67^{2}$ & $9,17^{\circ}$ & $9,83^{\circ}$ & $9,50^{\circ}$ & $9,00^{\circ}$ & $9,33^{\circ}$ & $8,67^{\mathrm{c}}$ & $7,67 \mathrm{~cd}$ & $7,50^{\circ}$ \\
\hline $\mathrm{K} 2$ (kappaphocus $100 \mathrm{~g}$ pot) & $1,00^{3}$ & $1,33 \mathrm{c}$ & $1,50^{\circ}$ & $1,83^{\circ}$ & $1,67^{\circ}$ & 2,179 & $1,50^{f}$ & 2,830 & $3,677^{\circ}$ & $4,33^{\circ}$ \\
\hline $\mathrm{G1}$ (gracilaria $10 \mathrm{gpot}$ ) & $3,00^{2}$ & $8,67^{2}$ & $8,67^{7}$ & $8,83^{\circ}$ & $8,67^{\circ}$ & $8,50^{\mathrm{cd}}$ & $8,33^{6}$ & $8,17^{66}$ & $6,33^{\mathrm{t}}$ & $6,50^{\mathrm{cd}}$ \\
\hline G2 (gracilaria $100 \mathrm{~g}$ pot) & $2,33^{4}$ & $4,83^{\circ}$ & $7,50^{\circ}$ & $12,50^{\circ}$ & $15,00^{\circ}$ & $15,67^{\mathrm{5}}$ & $16,17 \mathrm{~b}$ & $16,00^{\circ}$ & $15,33^{\circ}$ & $14,67^{\circ}$ \\
\hline
\end{tabular}

Keterangan: Angka yang diikuti oleh huruf yang sama pada kolom yang sama tidak berbeda nyata, uji Duncan $a=0,05$

Tabel 6. Jumlah malai tanaman padi

\begin{tabular}{|c|c|c|c|c|}
\hline PERLAKUAN & & Nillai & tha-rata & \\
\hline CO (Kontrolltanpa perlakuan) & $0,50^{4}$ & $2,67^{6 \mathrm{se}}$ & $7,67^{\circ}$ & $8,17^{b}$ \\
\hline $\mathrm{Cl}(\mathrm{N}, \mathrm{P}, \operatorname{dan} \mathrm{K})$ & $0,00^{3}$ & $8,67^{\circ}$ & $15,33^{a}$ & $16,33^{3}$ \\
\hline SI (sargassum 10 gpot) & $0,00^{\circ}$ & $1,83^{6 \mathrm{xa}}$ & $5,50^{\circ}$ & $5,88^{36 \mathrm{c}}$ \\
\hline S2 (sargassum 100 g pot) & $0,00^{3}$ & $0,6^{2 \mathrm{~d}}$ & $2,00^{\circ}$ & $3,33 \mathrm{~d}$ \\
\hline KI (kappaphyycus 10 g ppot) & $0,50^{\circ}$ & $4,00^{b c}$ & $7,33^{\circ}$ & $7,50^{\circ}$ \\
\hline K2 (kappaphyycus 100 g/pot) & $0,00^{\circ}$ & $0,00^{d}$ & $0,50^{d}$ & $1,67^{d}$ \\
\hline GI (gracilaria 10 gpot) & $0,33^{3}$ & $4,83^{\circ}$ & $6,50^{\circ}$ & $6,50^{b}$ \\
\hline G2 (gracilaria 100 g ppot) & $0,00^{2}$ & $4,67^{\circ}$ & $11,67^{b}$ & $14,33^{2}$ \\
\hline
\end{tabular}

Keterangan: Angka yang diikuti oleh huruf yang sama pada kolom yang sama tidak berbeda nyata, uji Duncan $a=0,05$
Tabel 7. Berat kering atas tanaman padi

\begin{tabular}{|c|c|}
\hline PERLAKUAN & $\begin{array}{c}\text { BERAT KERING ATAS TANAMAN PADI } \\
\text { (gram) }\end{array}$ \\
\hline CO (Kontrol tanpa pertakuan) & $14,82^{2 x}$ \\
\hline $\mathrm{Cl}($ pupuk N, P, dan K) & $45,33^{3}$ \\
\hline SI (sargassum 10 gpot) & $12,33^{6}$ \\
\hline S2 (sargeassum 100 gpot) & $8,12^{d}$ \\
\hline KI (kappaphycus 10 gpot) & $12,38^{\mathrm{i}}$ \\
\hline K2 (kappaphycus 100 g pot) & $5,42^{d}$ \\
\hline GI (gracilaria $10 \mathrm{~g} p \mathrm{pot})$ & $11,93 x^{x}$ \\
\hline (G2) (gracilaraia 100 gpot) & $25,63^{b}$ \\
\hline
\end{tabular}


Pemupukan pada perlakuan C1 dengan menggunakan pupuk anorganik atau pupuk kimia memiliki kelebihan dibandingkan dengan menggunakan pupuk organik. Kelebihan dari pupuk anorganik menurut Sutedjo (2002) yaitu penggunaan pupuk anorganik dapat disesuaikan dengan kebutuhan hara di dalam tanah dan tanaman, mudah didapat, meringankan biaya dalam pengangkutan, unsur hara cepat tersedia bagi tanaman karena sifat dari pupuk anorganik yang mudah larut, dan dapat disimpan lama. Tetapi pupuk anorganik juga memiliki kelemahan dalam pengaplikasiannya. Kelemahan dalam penggunaan pupuk anorganik menurut Winarso (2005) yaitu penggunaan pupuk anorganik secara intensif dan dalam jangka waktu yang panjang akan mengakibatkan adanya kerusakan pada struktur tanah, dan pencemaran air, selain itu penggunaan pupuk organik dapat menurunkan kualitas tanah dan terjadi kerusakan lingkungan.

Pemupukan yang dilakukan pada perlakuan G2 (penambahan pupuk limbah rumput laut Gracilaria dosis $100 \mathrm{~g} / \mathrm{pot}$ ) sebagai pupuk organik, dapat meningkatkan produktivitas tanaman padi meskipun tidak sebaik dengan perlakuan $\mathrm{C} 1$, tetapi penambahan pupuk organik secara kontinu dapat memperbaiki produktivitas lahan (Hardjowigeno, 2010), penambahan unsur hara di dalam tanah, memperbaiki struktur tanah, meningkatkan KTK, meningkatkan kegiatan biologi di dalam tanah, serta menambah kemampuan tanah untuk menahan air. Penambahan limbah rumput laut Gracilaria juga dapat meningkatkan nilai $\mathrm{C} / \mathrm{N}$ di dalam tanah. Hasil analisis menunjukkan nilai $\mathrm{C} / \mathrm{N}$ terhadap kandungan bahan organik di dalam tanah pada perlakuan $\mathrm{C} 1$ (penambahan pupuk $\mathrm{N}, \mathrm{P}$, dan K) yaitu 2,07\% (sedang) sedangkan pada perlakuan G2 (penambahan pupuk limbah rumput laut Gracilaria dosis $100 \mathrm{~g} /$ pot) yaitu $2,48 \%$ (sedang).

Peningkatan nilai $\mathrm{C} / \mathrm{N}$ dalam kisaran 12-15 (Hanafiah) di tanah dapat memperbaiki aktivitas mikroba tanah, memperbaiki pertumbuhan vegetatif tanaman, dan sebagai pembentukan protein. Tanaman akan berwarna lebih hijau jika tumbuh pada tanah yang cukup akan kandungan hara nitrogen (Gambar 1).

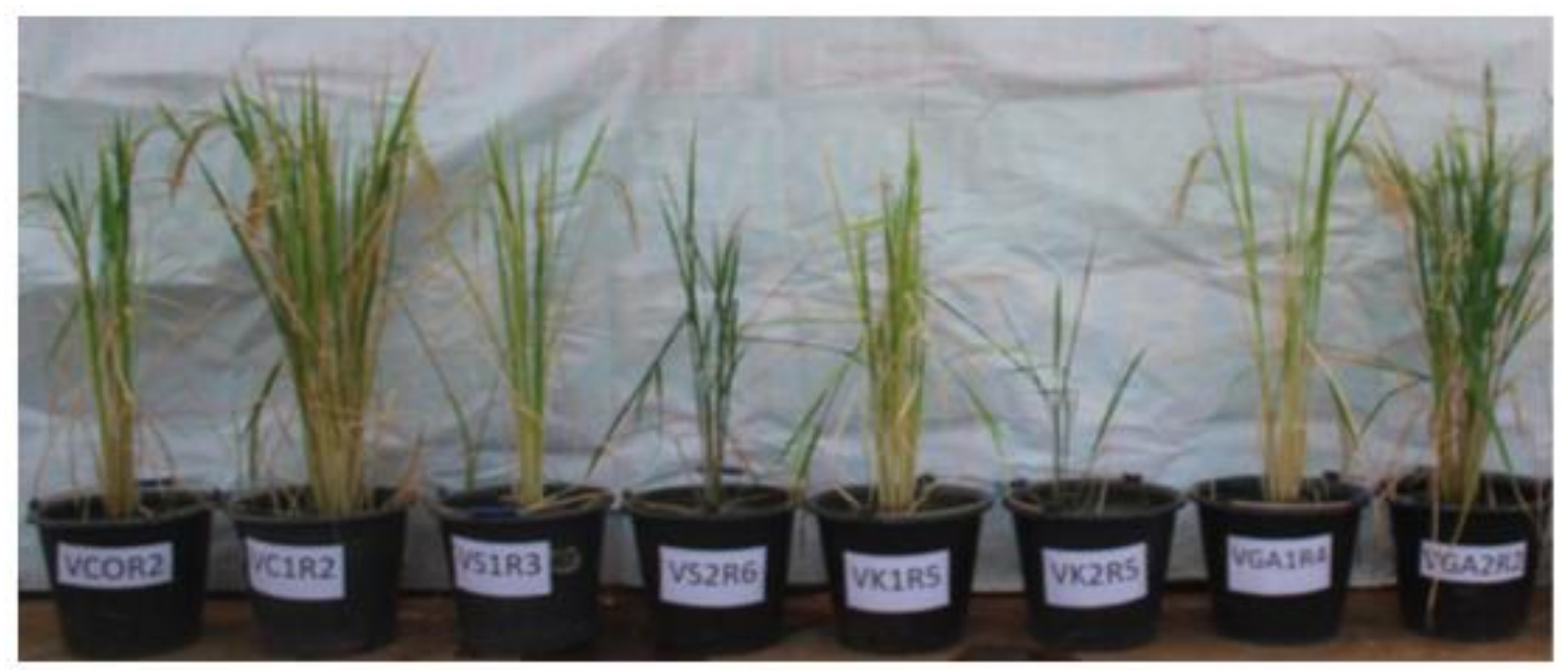

Gambar 1. Tanaman padi umur 84 HST (minggu 12) pada tanah Vertisol setelah perlakuan. 
Pada perlakuan K2 (penambahan pupuk limbah rumput laut Kappaphycus dosis 100 g/pot), produktivitas tanaman padi mengalami kemunduran. hal ini diakibatkan jumlah dosis yang diberikan melebihi dosis yang dibutuhkan oleh tanaman, sehingga tanaman menunjukkan gejala toksisitas dan menurunkan kemampuan tanaman dalam berproduksi. Gejala toksisitas ditunjukkan dengan nilai kandungan fospor di tanah yaitu $68,71 \mathrm{mg} / 100$ gr yang berada pada kriteria sangat tinggi (Balai Penelitian Tanah, 2005), jika dibandingkan pada perlakuan $\mathrm{C} 1$ (penambahan pupuk N, P, dan K) yaitu 37,40 $\mathrm{mg} / 100 \mathrm{gr}$ (sedang) dan pada perlakuan G2 (penambahan pupuk limbah rumput laut Gracilaria dosis 100 g/pot) yaitu 40,61 mg/100 gr (sedang), sedangkan kandungan fospor sebelum perlakuan yaitu $1,18 \mathrm{mg} / 100$ gr (sangat rendah) (Tabel 7). Kandungan fospor di tanah akan meningkat pada kondisi tergenang, sehingga penambahan fospor tidak diperlukan lagi, sedangkan tanaman aerob masih membutuhkan pemupukan fospor untuk memperoleh hasil produksi yang lebih tinggi (Sanchez, 1993).

\section{KESIMPULAN DAN SARAN}

\section{Kesimpulan}

1. Penambahan pupuk limbah rumput laut Kappaphycus dosis 100 g/pot (perlakuan $\mathrm{K} 2$ ) dapat meningkatkan nilai $\mathrm{N}, \mathrm{P}, \mathrm{K}$, dan $\mathrm{Ca}-\mathrm{dd}$, tetapi untuk produktivitas tanaman padi perlakuan K2 tidak maksimum karena adanya kemungkinan kelebihan dosis yang diberikan sehingga menghambat pertumbuhan tanaman dan menghasilkan bulir yang hampa, maka perlakuan tersebut tidak direkomendasikan.

2. Perlakuan G2 (penambahan pupuk limbah rumput laut Gracilaria dosis $100 \mathrm{~g} / \mathrm{pot}$ ) juga dapat memperbaiki sifat kimia pada tanah Vertisol meskipun tidak lebih baik dari perlakuan $\mathrm{C} 1$ tetapi kandungan hara nitrogen pada bulir padi lebih tinggi dibandingkan dengan perlakuan $\mathrm{C} 1$, selain itu perlakuan G2 (penambahan pupuk limbah rumput laut Gracilaria dosis 100 g/pot) memiliki pertumbuhan dan produktivitas yang tidak jauh berbeda dengan perlakuan $\mathrm{C} 1$ (penambahan pupuk N, P, dan K).

\section{Saran}

Sebaiknya dilakukan pengurangan dosis untuk penggunaan pupuk limbah rumput laut jenis Kappaphycus dan Sargassum, selanjutnya dilakukan pengujian kembali untuk menemukan dosis yang seimbang sebelum diaplikasikan di lapangan.

\section{PUSTAKA}

Aslan, L. M. 1995. Budidaya Rumput Laut. Kanisius.Yogyakarta.

Badan Pusat Statistik (BPS). 2015. Produksi Padi Jagung. dan Kedelai (Angka Sementara Tahun 2014). Berita Resmi Statistik : 1-3.

Foth, H. D. 1994. Dasar Ilmu Tanah. Terjemahan: Adisoemarto. Erlangga. Jakarta

Hanafiah, K. A. 2005. Dasar-dasar Ilmu Tanah. Raja Grafindo Persada. Jakarta.

Hardjowigeno, S. 2010. Ilmu Tanah. Ed. Baru. Akademia Pressindo. Jakarta.

Indranada, H. 1989. Pengelolaan Kesuburan Tanah. PT Bina Aksara. Jakarta

Sharma, OP. 1992. Text Book of Algae. Tata Mc Graw-Hill Publishing Company Lim-ited. New Delhi: 73 - 79.

Sanchez, P.A. 1993. Sifat dan Pengelolaan Tanah Tropika. Penerbit ITB. Bandung.

Sutedjo, 2002. Pupuk dan Cara Pemupukan. Rineka Cipta. Jakarta.

Winarso, S. 2005. Kesuburan Tanah, Dasar Kesehatan dan Kualitas Tanah. Gava Media. Yogjakarta. 